\title{
A Review of Media Primitivism
}

\author{
ALEXANDRA M. THOMAS \\ PhD Candidate, Yale University
}

\section{ABSTRACT}

This is a review of Delinda Collier's 2020 book, Media Primitivism: Technological Art in Africa, that examines its importance to the fields of art history and media studies. Collier raises fundamental concerns about racist allegories that are often left unquestioned in foundational media theory texts. In so doing, she engages the role of mediation in African art history without relying on primitivizing rhetoric.

\section{INTRODUCTION}

The insinuation that film is indigenous to Africa and the proposition that the first piece of electronic music is by an Egyptian man may be an affront to the sensibilities of eurocentric media scholars who rely on the primitivizing trope of Africans as technophobic. Enter Delinda Collier's Media Primitivism: Technological Art in Africa: the second book in "The Visual Arts of Africa and its Diasporas," a Duke University Press series edited by Kellie Jones and Steven Nelson. Perhaps it is a fundamental aspect of the field that African art history must do the work of rectifying errors of Western academic conceit while simultaneously charting innovative paths in the study of visual and expressive cultures. Indeed, Media Primitivism exposes the epistemic gaps and miscalculations in media theory that belie the pivotal role of Africa in media and technology art. Where sister disciplines often function more like estranged cousins, Collier interrogates the frictions between African art history and media theory. She narrates entanglements of the fields in such a way that frames the objects she analyzes, largely film and sound art.

\section{SUMMARY}

Media Primitivism is organized into six chapters with an introduction and an afterword - each of which negotiates a complicated understanding of mediation, technology, and Africa. The introduction, "African Art History and the Medium Concept," is an intricate web of theoretical discourse, mined by Collier to provide a solid framework through which to interpret the rest of the book. Teasing out an approachable definition for the phraseology of "Media Primitivism" can be done through engaging the use of allegory (a term pulsing through the book's web of argumentation). To demonstrate, Collier returns to the discourse of fetishism, which she identifies as an "allegory, further abstracted to become pseudofact used in theories of art and art history." Collier's intervention proposes that fetishism is not just about spirituality and economics, but about technology as well. "Fetish is to fetishism as race is to racism: a misplaced concreteness attributed to people and their material objects," she explicates. Accusations of fetishism in African art history, 
levelled by early modern European travelers on the West African coast and their Enlightenment heirs, supposes that African art is always "natural material" and thus "non-technological and nonphilosophical."2 Media primitivism, as a concept, confronts the allegorical rhetoric through which African art is imagined as simplistic or unsophisticated due to its perceived lack of mediation and technology.

Chapter one, "Film as Light, Film as Indigenous," grapples with the indigeneity of African cinema, highlighting Dogon cosmologies in the film Yeelen by Malian filmmaker Souleymane Cissé. Chapter two, "Electronic Sound as Trance and Resonance" contains an insightful analysis of Egyptian musician Halim El-Dabh's (1921 - 2017) Ta'abir Al- Zaar/ The Expression of Zaar (1944), which Collier details as an example of musique concrète prior to Pierre Schaeffer. Chapter three, "The Song as Private Property," engages the artwork featured on the cover of the book: the 8-channel audio collage installation, Song of Solomon (2006), which pays tribute to Solomon Linda's 1939 song, Mbube, which was appropriated by folk singer Pete Seeger into the mistranslated Wimoweh (1952) before becoming The Lion Sleeps Tonight (1961) and earning millions. Linda died in 1962 in poverty, but his family was paid almost \$2 million in damages in 2006. Chapter four, "Artificial Blackness, or Extraction as Abstraction," is concerned with James Webb's use of allegory in his installation The Black Passage (2006), a sound recording of an empty elevator in the South Deep gold mine in South Africa, and is staged as a square of black speakers framed with light, paralleling Kazimir Malevich's Black Square (1915). The chapter looks toward how allegory is utilized to abstract labor and race oppression in the mines. Chapter five, "The Earth and Substratum Are Not Enough," is about Lubumbashi-based artist Jean Katambayi Mukendi's series of "antifetishes, or prototypes," which are "assemblages that address and demonstrate flows of energy and its mathematical representation." 3 One such work is Ecoson (2010), in which Katambayi makes visible how electricity becomes electronics, and exposes the mysteries of technology in order to make apparent the labor demands to keep electricity flowing. Chapter six, "The Seed and the Field," is in part about the black and feminist readings of art and technology in Kenyan filmmaker Wanuri Kahiu's digital short film Pumzi (2009), in which there is a dystopic "virtual natural history museum" where the protagonist Asha ultimately plants a seed in the East African landscape to "restore Africa to a fertile rainforest." In the afterword, Collier reiterates that while the book is largely set in the twentieth century, "the intellectual history reaches back to the Enlightenment, the moment when fetish and fetishism become allegorical of difference."5

\section{MEDIA PRIMITIVISM}

Collier began grappling with media primitivism in her first book, Repainting the Walls of Lunda: Information Colonialism and Angolan Art (University of Minnesota Press, 2016) but decided to flesh it out more capaciously in her second book. "Media Primitivism" is a provocative and generative term: the radical critiques its laced with are essential for media scholars to take seriously. At times, the book's prose feels impenetrable, but its linguistic prowess, I believe, is necessary for adequate engagement with such a complex network of theory, history, and politics. In particular, the term "primitivism" in art history recalls primitivist modernism, as exemplified in William Rubin's 1984 exhibition at the Museum of Modern Art in New York, "Primitivism" in 20 $0^{\text {th }}$ Century Art: Affinity of the Tribal and the Modern. The forefathers of media theory took a primitivizing (read: racist) stance on African art, much like the European and American harbingers of modernism. The historical avant-gardes in modern art history who appropriated African aesthetic forms in the formation of an art historical canon that remained anti-Black, can be compared to 
Western media theorists who look toward their imagination of Africa without rigorous engagement of its histories. Much like discourse on primitivist modernism in art history starts with Pablo Picasso, the construction of media primitivism might begin with Marshall McLuhan. "Primitivism is obviously found in Hegel's and Marx's theories, but it lurks still nearly unexamined in Marshall McLuhan's infamous declaration that the natives of Ghana had no apparatus through which to understand new media," writes Collier. ${ }^{6}$ Cemented further in McLuhan's and Quentin Fiore's The Medium Is the Massage (1967), when, in a two-page visual spread, "a group of black unclothed people (neither Ghanaian nor urban African) gathers around a storyteller who raises his arms up to emphasize a spoken exclamation," with the caption: "The new electronic independence recreates the world in the image of a global village." 7 This cringe-worthy rhetoric on the part of media studies' foundational figures is, as Collier names, a "racializing mechanism of media studies." ${ }^{\text {It }}$ presents an intellectual apparatus through which to engage mediation that is undoubtedly influenced by racist, primitivizing narratives.

Yet, Media Primitivism must not be interpreted as a mere reparative gesture to right the wrongs of racist rhetoric in the field of media studies. It does much more than that in raising philosophical questions about the nature of media in relation to African art history. Collier's analysis of electricity is exemplary of the book's epistemic shifts regarding how we theorize technology. She describes the "hypermediality of electrity-based art" as an "African way of doing art," and equates it to energy, as in the Mande concept of nyama. "Such concepts are culturally marked," she writes, "but seek to describe something as yet unmarked and unmediated." "Water, light, airwaves, electromagnetism, "alchemy" are among the substances mediated by technology throughout the book. That approach is among the most potent aspects of the text, as Collier seeks to shift how we think media, technology, and the elements in contrast to approach that merely hopes to prove there is "new media art in Africa." She even avoids the use of the term "new media" which is apropos to her method of historicizing and investigating media histories on the continent that are embedded into African cultures, and as such, not "new."

\section{CONCLUSION}

Overall, Media Primitivism is a compelling book that blends media theory, art history, and African art history in a masterful act of theoretical weaving on the part of its author. The book should be of interest to students and scholars in all three fields, as well as those in anthropology who are interested in the notion of contextualization and mediation. It should be read by those in sound studies especially in light of Collier's criticism of ocularcentrism in art history. Important interventions are staged for film studies regarding the distinct contributions of African cinema to the medium. It presents a nuanced and rigorous approach to African art history that that does not rely on the sensationalism of African media as novelty. Tracing deeper technological histories on the continent, and excavating western media histories that rely on Africa, proves that the question of Africa (as a place and idea) is not additive to media studies, but a foundational aspect of it.

\section{ENDNOTES}

${ }^{1}$ Delinda Collier, Media Primitivism: Technological Art in Africa (Durham: Duke University Press, 2020), 2.

${ }^{2}$ Collier, Media Primitivism, 7. 
${ }^{3}$ Collier, Media Primitivism, 154.

${ }^{4}$ Collier, Media Primitivism, 186.

${ }^{5}$ Collier, Media Primitivism, 212.

${ }^{6}$ Collier, Media Primitivism, 7.

${ }^{7}$ Ibid.

${ }^{8}$ Ibid.

${ }^{9}$ Collier, Media Primitivism, 3.

\section{REFERENCES}

Collier, Delinda. Media Primitivism: Technological Art in Africa (Durham: Duke University Press, 2020).

\section{AUTHOR BIO}

Alexandra M. Thomas (alexandra.m.thomas@yale.edu) is an art critic, emerging curator, and educator with a focus on visual and expressive cultures of Africa and the African diaspora, black feminism, and queer theory. She is a PhD candidate in History of Art and African American Studies, with a certificate in Women's, Gender, and Sexuality Studies at Yale University. 